\title{
A Review of European Grid Service Markets Suitable for Distributed Loads
}

\author{
Tanaka Mandy Mbavarira \\ Lucerne School of Engineering and Architecture \\ Christoph Imboden
Lucerne School of Engineering and Architecture
}

Insufficient and unreliable data regarding European ancillary service markets lead us to carry out a survey aimed at collecting data from European transmission and distribution system operators for the purpose of understanding the markets' capacity for accommodating distributed loads, such as water electrolysers, as balancing service providers. A review of literature enhanced the survey knowledge base in cases where surveys were not responded to. At the time of writing, the markets found to be closed to the participation of water electrolysers, included Croatia, Czech Republic, Estonia, Latvia, Lithuania, Poland, Portugal, Romania and Spain. The European grid service market landscape is highly heterogeneous, with contrasts seen in market rules, transparency, technical requirements and price levels. In this report, we present the availability and utilisation prices of balancing products which are technically suited to electrolysers. We provide an overview of the market conditions and the countries found to be most favourable with respect to remuneration. Finally, we address that distribution grid services are not readily offered by distributed system operators.

Keywords: European electricity grid service markets, distributed loads, Frequency Containment Reserve (FCR), automated Frequency Restoration Reserve (aFRR), manual Frequency Restoration Reserve (mFRR), Restoration Reserve (RR), availability prices, utilisation prices

\section{INTRODUCTION}

The European Union (EU) Horizon 2020 framework, in a public-private partnership with the Fuel Cell Hydrogen Joint Undertaking (FCH-JU), supports research in sustainable hydrogen production. With this sponsorship, a survey was carried out in order to obtain primary data on EU electricity grid service markets in an effort to uncover their business logic under the QualyGridS research project (Project 735485, www.qualygrids.eu). Distributed fast variable loads, such as water electrolysers (WEs), have the potential to provide grid services. Their flexibility can be offered to transmission system operators (TSOs) for the provision of balancing services, such as frequency containment reserve (FCR), frequency restoration reserve (FRR), or to distribution system operators (DSOs) for congestion management and voltage control among others [1, p. 37-38]. European TSOs and DSOs were the target population of the survey. The purpose of this report is to present the findings. 


\section{BACKGROUND}

Due to the lack of reliable market data in literature, two surveys were conducted: one specifically for TSOs and another specifically for DSOs. The surveys were sent to 36 TSOs from 30 countries (EU-28 plus Switzerland and Norway). The TSO questionnaire offers a brief background on the grid services of particular interest elaborated in Table 6: FCR, aFRR, mFRR and RR followed by a mixture of closed-ended questions pertaining to the grid service characteristics (e.g. Is a load accepted for the provision of the service?), technical requirements (e.g. What is the requested minimum output duration of one activation?). The utilisation and availability prices for the year 2016 were also requested. With open-ended questions, the final section solicits information regarding general market trends and the existence of aggregators ${ }^{1}$ on the market.

Unlike TSOs, a country can have hundreds of DSOs; hence, 143 DSOs spanning all 30 countries were randomly selected for the survey. The questionnaire consisted of a section enquiring about the level of demand for the grid services (e.g. How many hours per year would you typically activate the service?) and their valuation (e.g. How much would you pay for the availability?). The following section enquires about any additional services specific to the country in question and that can be provided by flexible loads e.g. voltage control. The final section goes on to solicit general information regarding trends affecting the DSO markets, active aggregators and knowledge of any pilot projects testing DSO grid services.

For both questionnaires, the number of questions was kept to a minimum in order to increase the response probability. They were sent out in the winter of 2017/2018 via email and post with addresses sourced from the company web pages and, where possible, to individual DSO members. The TSO response rate was $30 \%$ where 12 out of 36 TSOs answered and returned the questionnaires. The DSO response rate was $4 \%$ where 6 out of 143 responses were returned from Spain, Bulgaria, Ireland, Latvia, Slovenia and Czech Republic. Results from the survey were cross-checked with our understanding of the business logic underlying the TSO grid service markets and key sources as summarised in Table 1. Where necessary, results from the survey were cross-checked by means of telephone interviews conducted with TSO and DSO representatives throughout 2018/2019.

TABLE 1

GRID SERVICE MARKET KNOWLEDGE BASE

\begin{tabular}{|l|}
\hline Information Category \\
\hline Balancing market surveys \\
\hline TSO balancing products price and volume data repositories \\
\hline TSO market design proposals \\
\hline
\end{tabular}

Although widely used by TSOs for reporting balancing prices and volumes, it came to light that Enstoe's transparency platform [6] at that time of writing was not coherent and sufficiently easy to interpret. The reason for this is thought to be attributed to the fact that each TSO is given the responsibility of uploading their own data. As a result, varied interpretation of the data was required in addition to verification of the interpretation, without which the data would be unreliable.

\section{RESULTS}

\section{TSO Survey Results}

The heterogeneous nature of the national data and data quality available made it difficult to assess some cases; to this end, evaluation of the TSO grid services is based on a combination of literature, expert interviews and the survey. Malta is the only country without a TSO. The following countries did not reply to the survey: Italy, France, UK, Belgium, Bulgaria, Spain, Croatia, Cyprus, Czech Republic, Estonia, Hungary, Latvia, Lithuania, Luxemburg, Portugal, Romania and Slovakia. However, it could be confirmed from the Entso-e and /or SEDC surveys that Croatia, Estonia, Latvia, Lithuania, Poland, Portugal, Romania 
and Spain do not accept non-rotating masses and/or loads for the provision of TSO grid services. In the case of France, additional channels were explored to get into contact with the TSO, but with no response. Hence, only official documentation was consulted. Although no response came from the UK, it was possible to establish a working channel of communication with the TSO for the provision and verification of data. The result was 85 TSO grid services were identified as candidate cases for the application of distributed variable loads in the TSO grid service markets from the 30 countries. The following tables display a mix of the empirical data obtained from the survey in addition to secondary data from Entso-E and SEDC. FCR, aFRR and mFRR refer to groups of sub-products, which can be found in detail in Table 6 .

\section{LOAD PARTICIPATION ('ACCESS') FOR DIFFERENT PRODUCTS IN EU COUNTRIES}

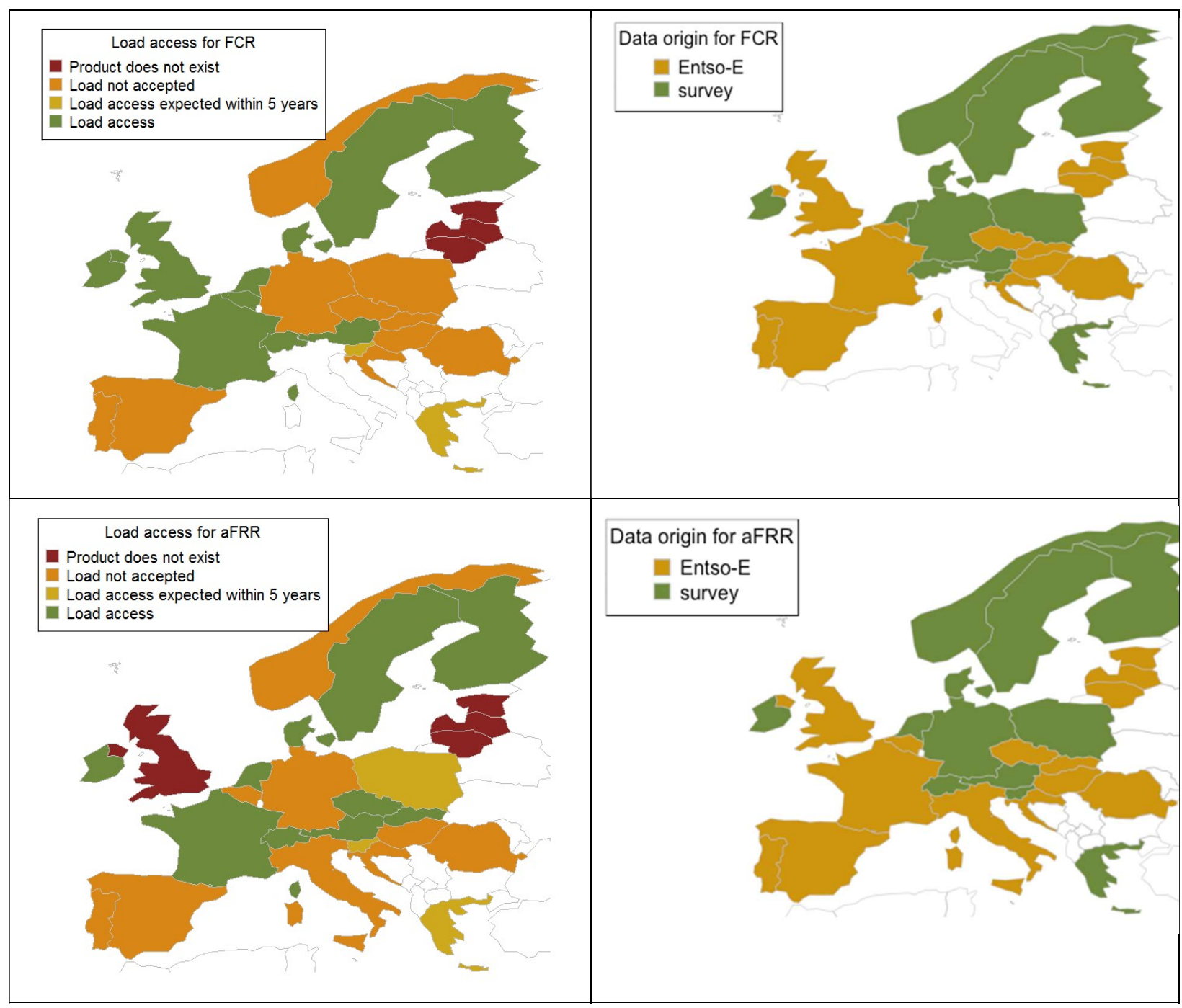




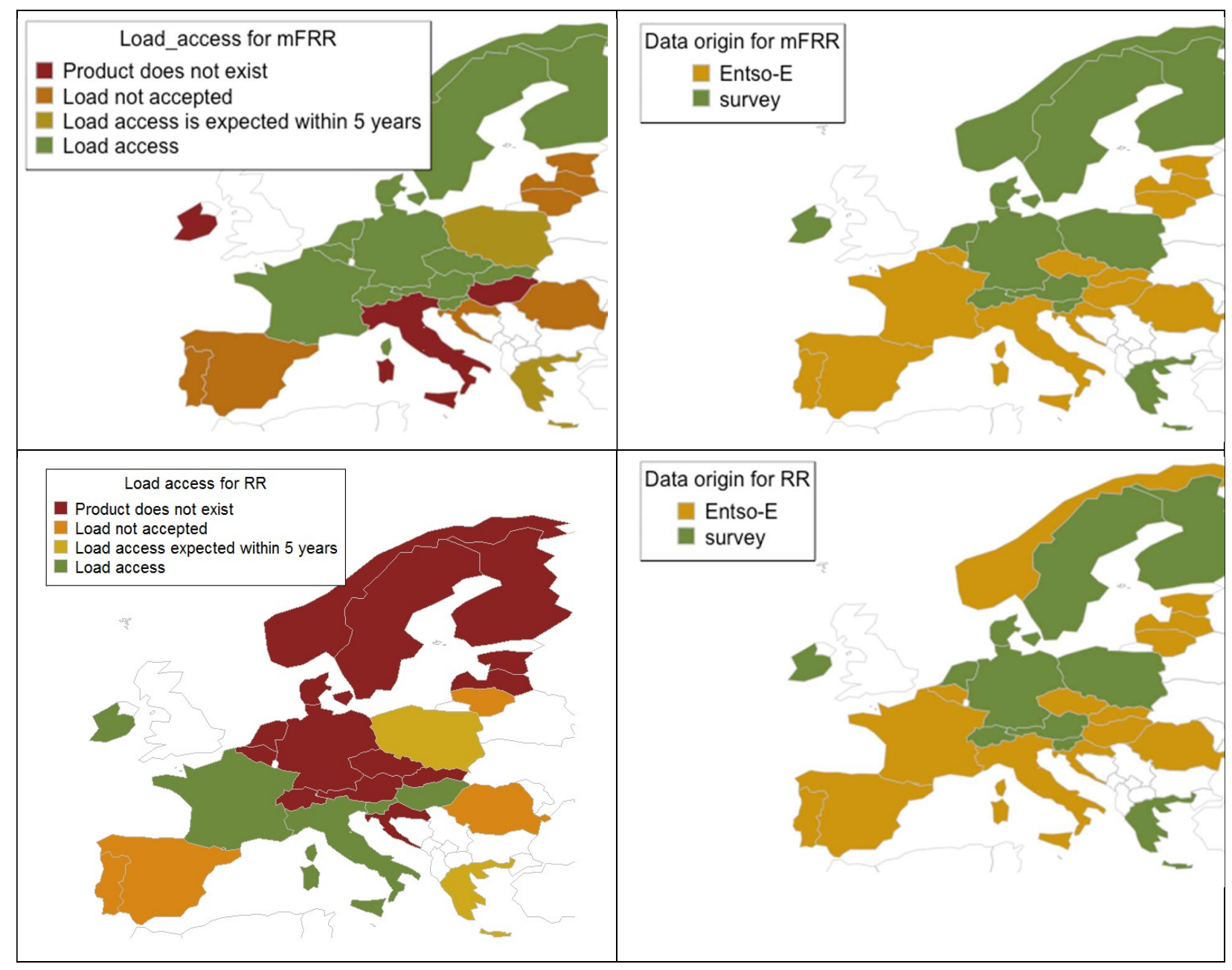

TABLE 3

NON-ROTATING MASS ACCESSIBILITY FOR DIFFERENT PRODUCTS IN EU COUNTRIES

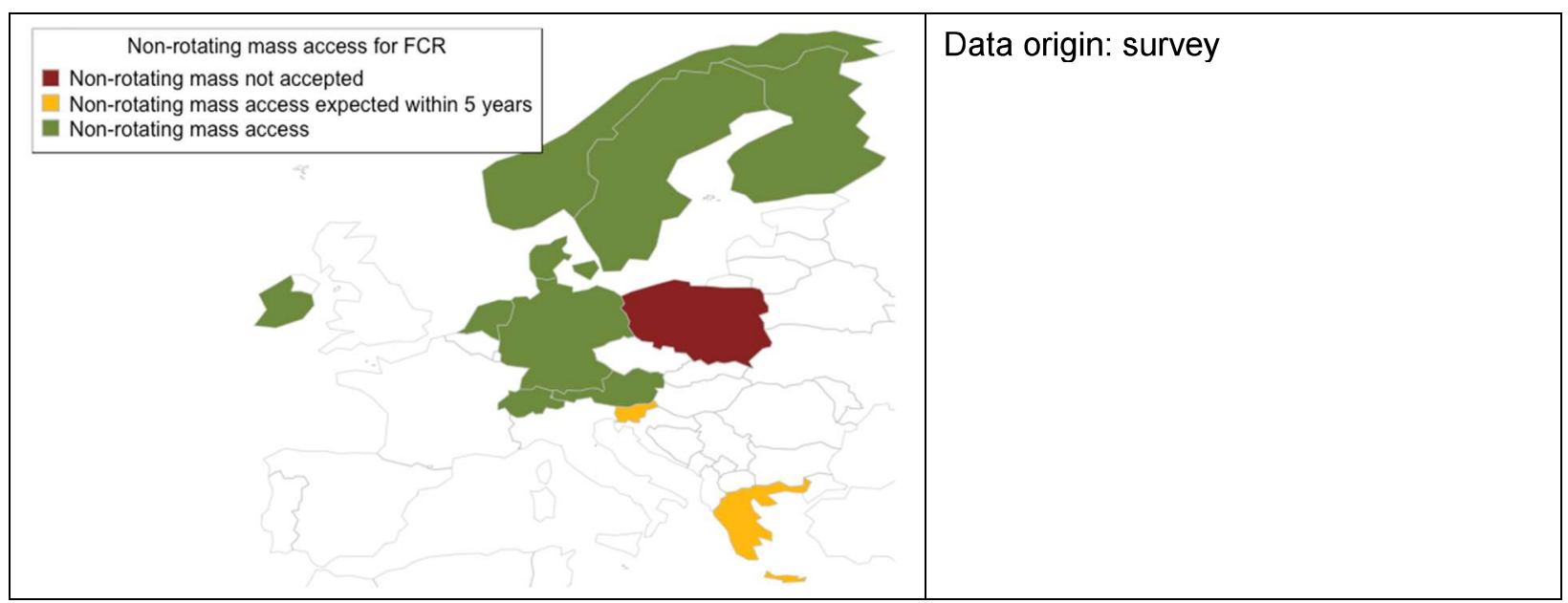




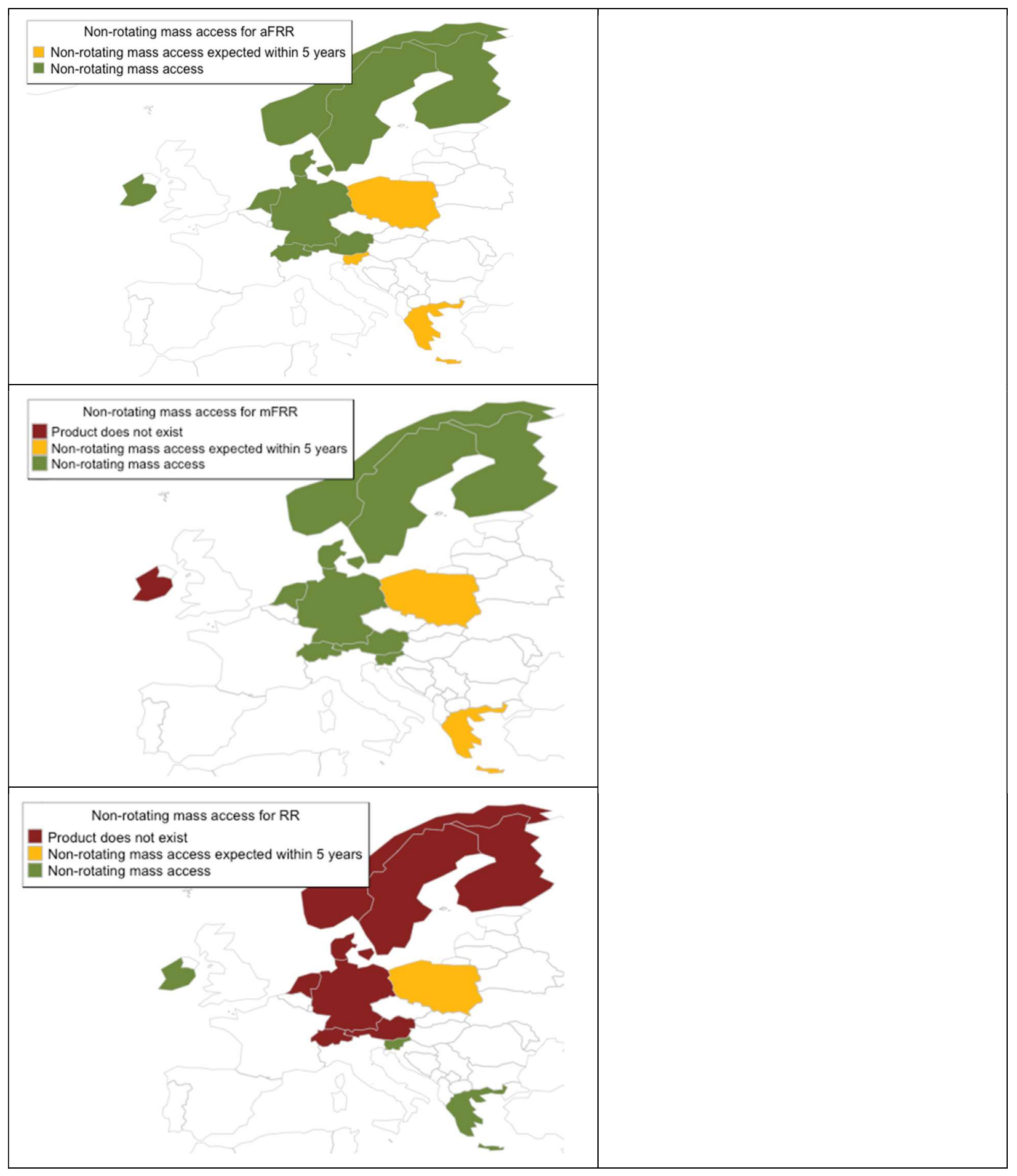

92 Journal of Strategic Innovation and Sustainability Vol. 15(8) 2020 
TABLE 4

POSSIBILITY OF AGGREGATION

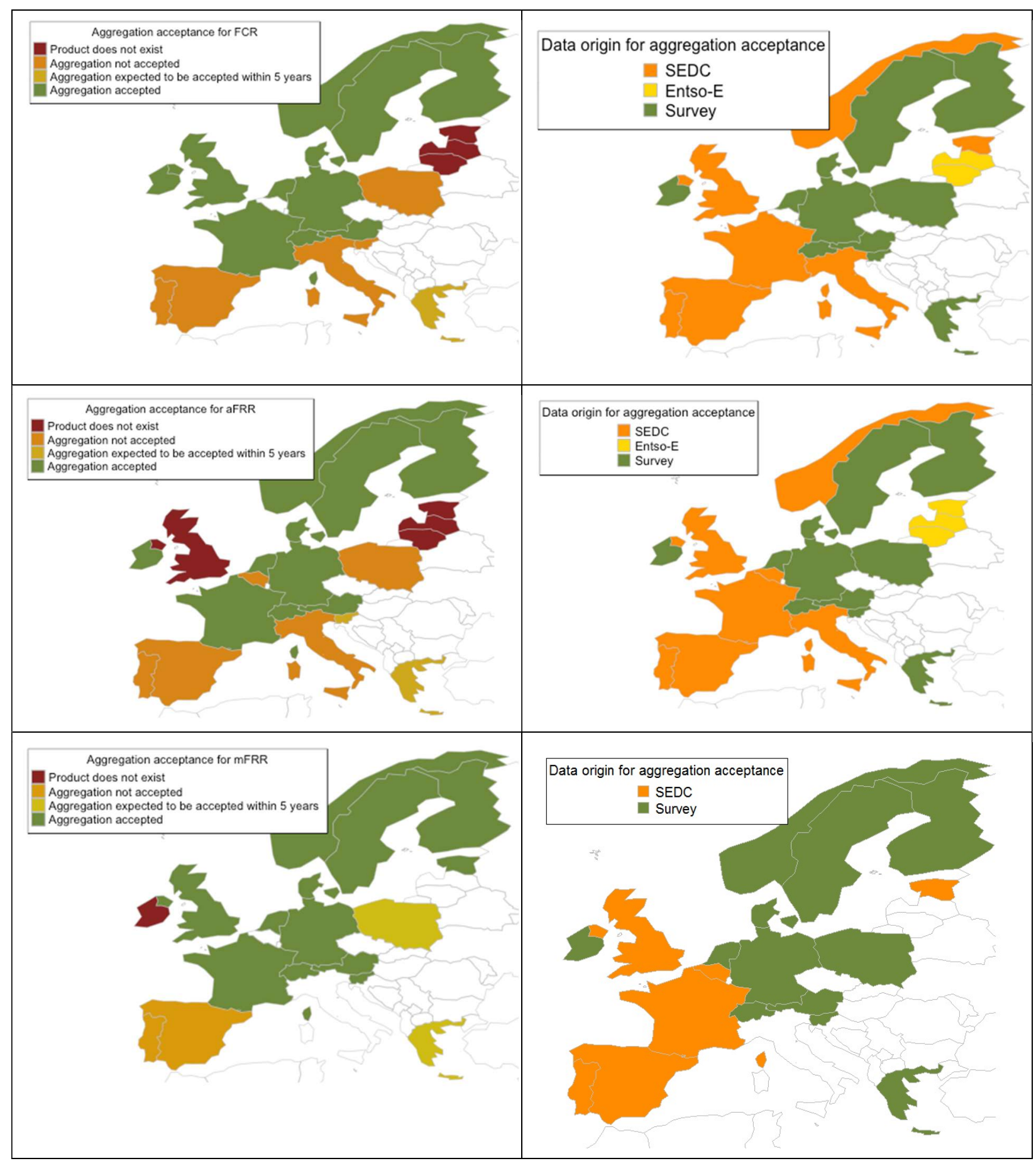




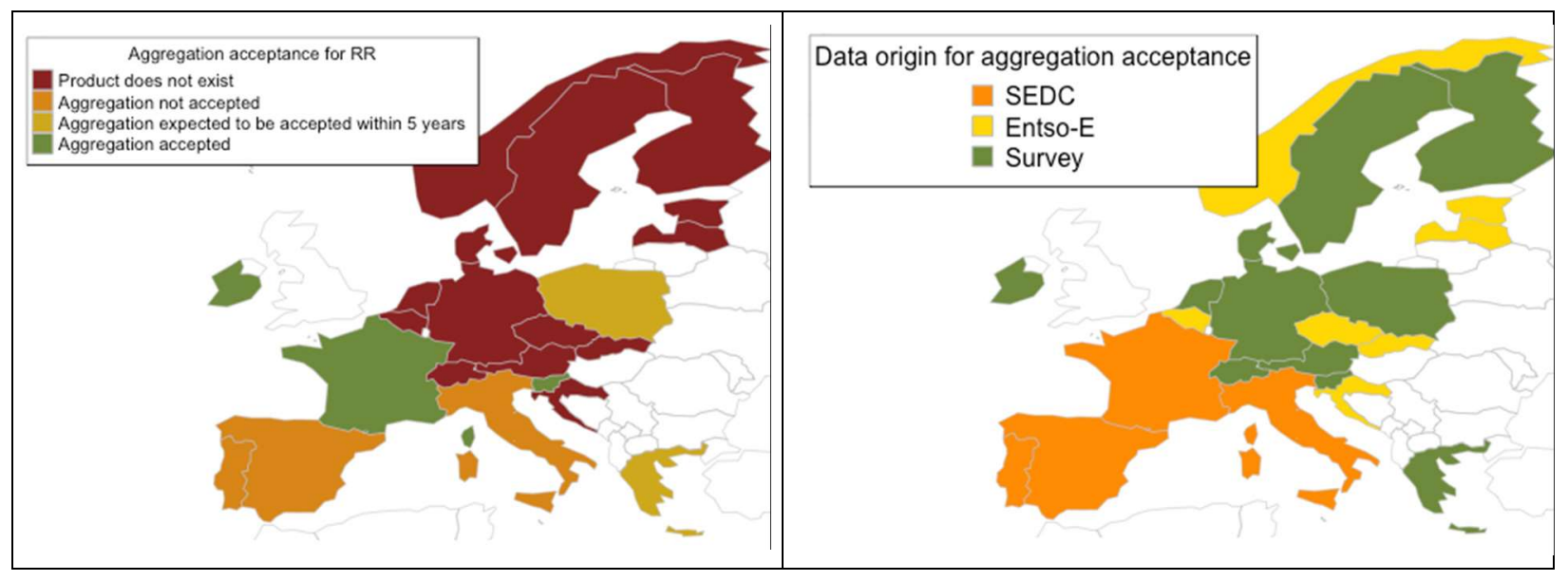

TABLE 5

PRODUCT SHAPE (E.G. PRODUCTS WITH WEEKLY, DAILY OR HOURLY BLOCKS)

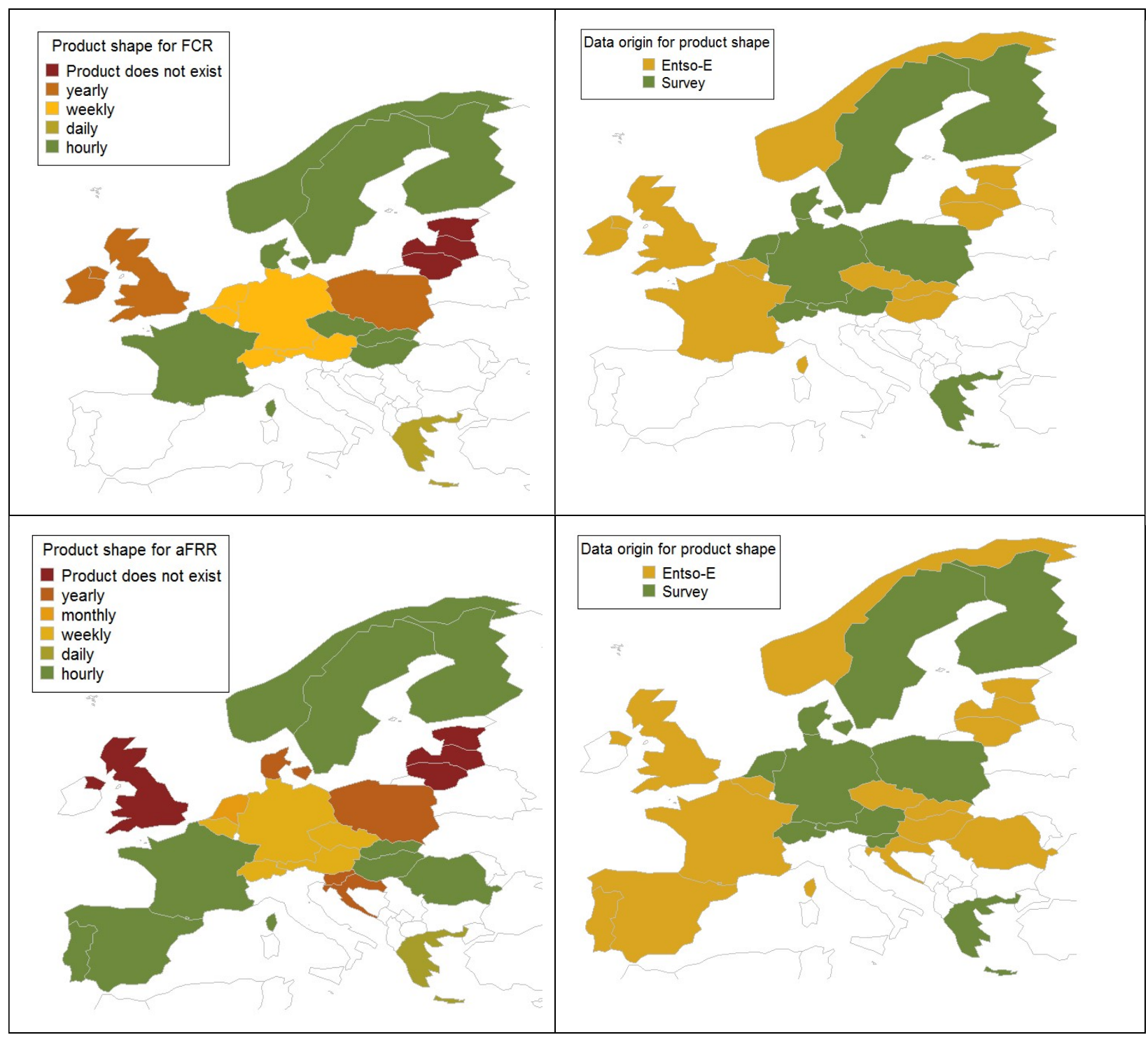

94 Journal of Strategic Innovation and Sustainability Vol. 15(8) 2020 


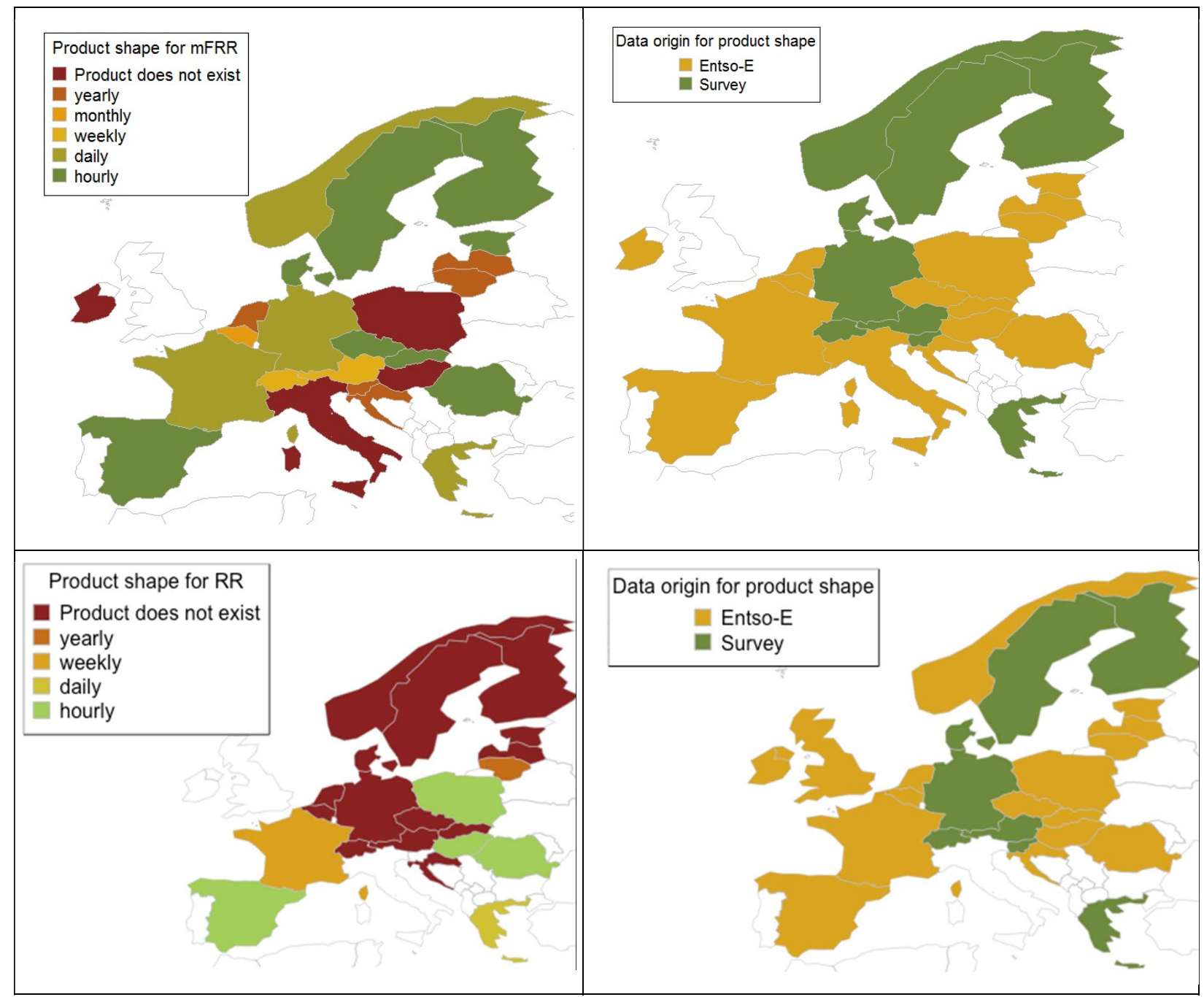

From Table 2, the following can be seen:

- The aggregation is widespread.

- mFRR is the most accessible market for distributed loads with regard to load access and the possibility of aggregation (with Ireland's mFRR being the only one closed to aggregation).

- Product shapes are predominantly hourly.

- The Baltic states are mainly characterised as having mFRR yearly markets (apart from Lithuania's yearly RR and Estonia's hourly mFRR market) and as such can be characterised as being relatively closed and undeveloped markets.

- Greece and Poland in particular are expecting their balancing markets to be more accessible by 2021 with regard to the possibility of aggregation and load access.

- Markets found to be closed to aggregation are Poland, Portugal and Spain, with Poland expecting this to change for mFRR and RR by 2021.

- Markets found to be closed to non-rotating masses are Croatia, Czech Republic, Estonia, Latvia, Lithuania, Poland, Portugal, Romania and Spain.

Additionally, the following general market conditions were ascertained:

- The Nordic countries predominantly have a pay-as-cleared settlement rule for the procurement of capacity and energy of ancillary services, whereas the majority of countries utilise pay-as- 
bid (Austria, Switzerland, Germany, UK) and others, such as France, utilise pay-as-bid, pay-as cleared and regulated pricing depending on the markets and procurement type.

- Procurement schemes are largely market-based ${ }^{2}$; some countries also make use of a combination of markets and mandatory participation of generators ${ }^{3}$ (Denmark, France, Greece, Ireland, Norway and Poland).

- In many countries, RR does not exist and for Nordic countries the same is true as mFRR fulfils the role of $R R$.

- The majority of FCR products are symmetrical, in line with Entso-E regulation; however, a few asymmetric FCR products exist on the French and Nordic markets, such as the hourly and yearly FCR-D + in Finland, the yearly FCR-D+ in Denmark East and FCR+ and FCR- in Denmark West as indicated in Table 6.

- Denmark was found to have a unique market setup. Although belonging to two separate synchronous areas: Denmark East (DK2) and West (DK1), it is considered to be one synchronous area with regard to mFRR on the Nordic Regulation Power Market (NORD POOL). Norway supplies Denmark East's aFRR capacity over the Skagerrak interconnection via Denmark West through a five-year bilateral agreement (2015-2020).

- Expected changes in the next five years include: a shift towards shorter resolution products, e.g. hourly to quarter-hourly, an acceptance of rotating masses or loads for the provision of grid services in those countries where it is not already practiced, an acceptance of aggregation in those countries where it is not already practiced and a smaller accepted minimum bid size.

\section{Availability Prices}

TSO grid services are generally valorised by two means: remuneration for availability ('power reserve') of the service provider and remuneration for the utilisation ('energy'). Figure 1 shows the set of average availability prices per country and product for the year 2016. The values for symmetrical products are divided by two for comparability with asymmetrical products. There are significant price differences among the countries. For example, average remuneration of availability for FCR in Norway (FCR-N) is 3.4 $€ / \mathrm{MW} / \mathrm{h}$ while in Finland (FCR-N hourly) it is $34.7 € / \mathrm{MW} / \mathrm{h}$. Furthermore, availability of aFRR is remunerated in Finland at approximately 23 times higher than in Germany. Overall, the most favourable availability prices are exhibited by Finland, Switzerland and Denmark. In 2016, the Swedish TSO, Svenska Kraftnät, required only mFRR (which is remunerated for utilisation only) despite FCR and aFRR being tradable products on the balancing market. Hence, FCR and aFRR do not appear in Figure 1. Despite no demand for FCR and aFRR, their market prices shown in Table 6 are understood as being the result of the system price ${ }^{4}$, which is crucial for the price formation within other time windows such as the intra-day and balancing markets 


\section{FIGURE 1 \\ AVERAGE 2016 AVAILABILITY PRICES FOR FCR, FRR, AND RR AND COUNTRY- SPECIFIC PRODUCTS [€/MWH IN 2016]}

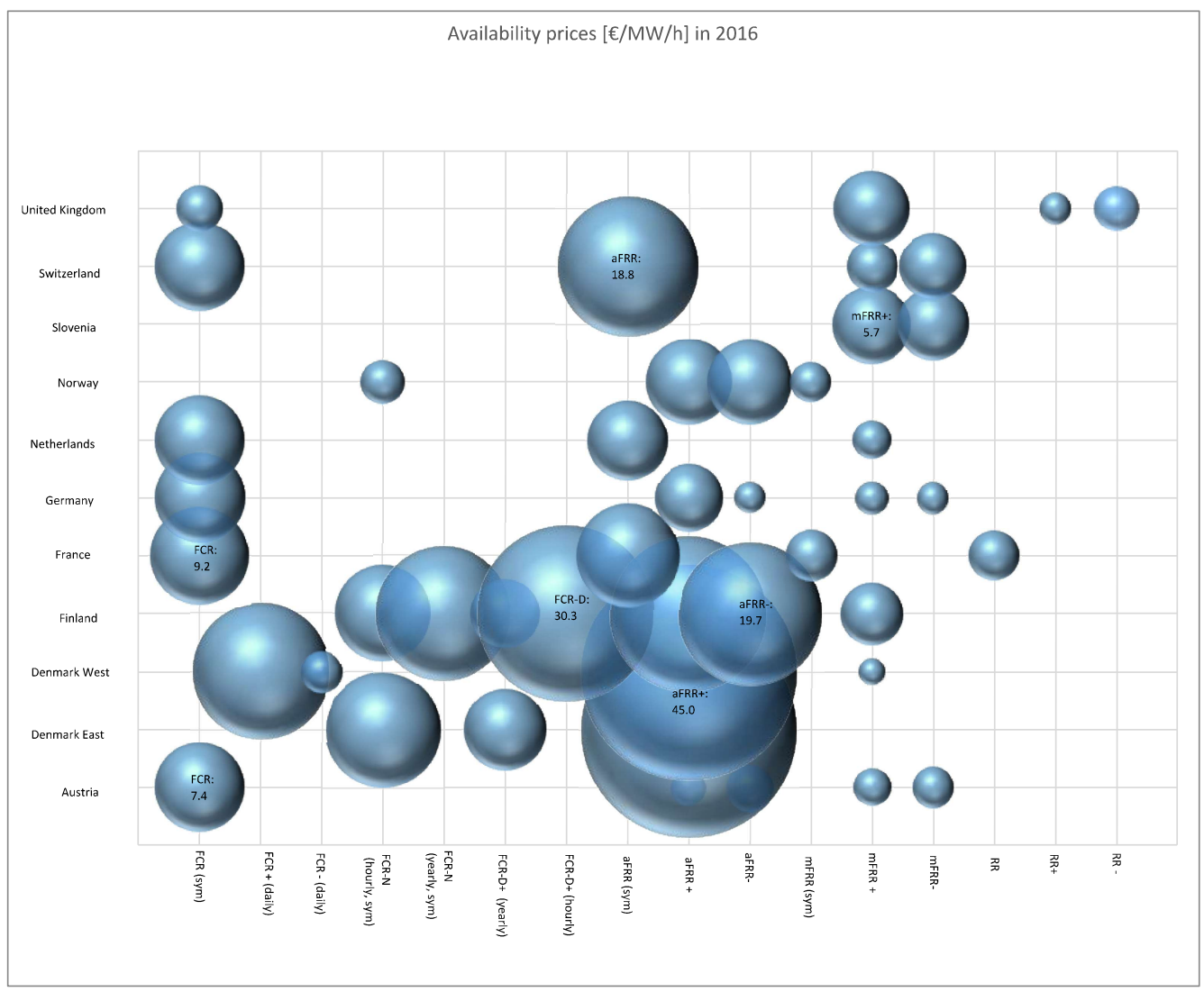

The bubble size corresponds to price. Values for symmetrical products are divided by two for comparability with asymmetrical products. For Ireland, availability prices for FFR, POR, SOR, TOR, TOR2 and $R R$ are available but very low $(\leq 3 € / \mathrm{MWh})$ with products that are not standardised and, therefore, not shown in the plot. The numeric price data can be found in Table 6 .

\section{Utilisation Prices}

Figure 2 shows the economic value added (EVA) from utilisation per country and product for the year 2016. The bubble areas are proportional to the EVA, where the additional income from activation is compared with a case where no income is received and the provider pays the average day-ahead price for electricity consumption, which is assumed to be constant and equal to the national SPOT base price. Austria (mFRR), Germany (mFRR) and the UK (RR) exhibit the most lucrative profits from their balancing products with respect to utilisation. The white bubbles exhibit cases with negative EVAs for example UK mFRR+. This is due to the day-ahead price of electricity $(47.44 € / \mathrm{MWh})$ for providing upward regulation costing more than the remuneration awarded for the service of upward activation of energy $(2.77 € / \mathrm{MWh})$. Effectively, the balancing service provider is running at a loss of $44.7 € / \mathrm{MWh}$. 
FIGURE 2

\section{EVA 2016 FROM UTILISATION FOR TSO GRID SERVICES}

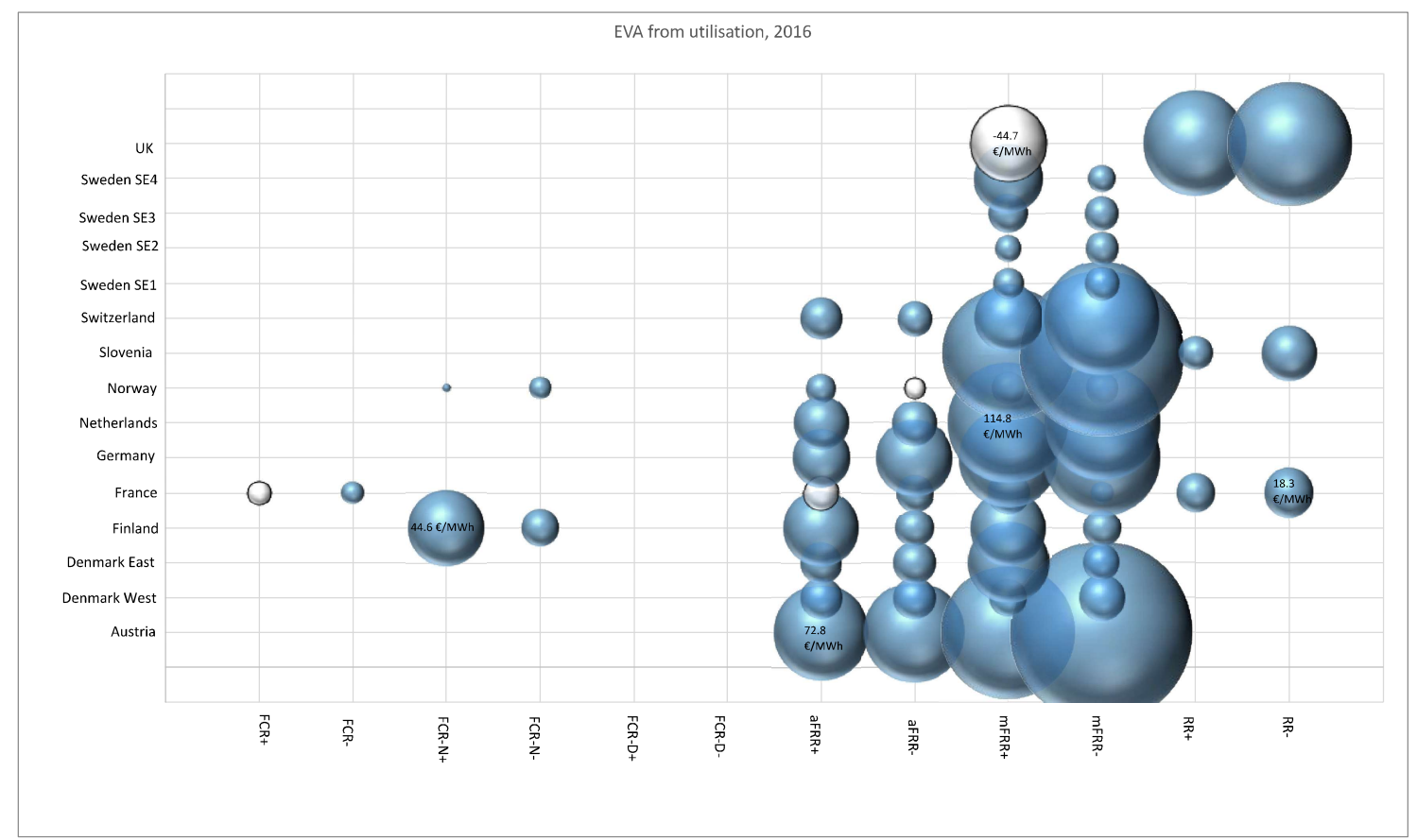

The area size corresponds to the EVA, where blue bubbles represent a positive profit and white bubbles represent a loss

TABLE 6

REFERENCES FOR AVERAGE PRICE DATA

\begin{tabular}{|c|c|c|c|c|}
\hline Country & Product & $\begin{array}{l}\text { Availability } \\
\text { price } \\
{[€ / \mathrm{MW} / \mathrm{h}]}\end{array}$ & $\begin{array}{l}\text { Utilisation price } \\
\text { [€/MWh] }\end{array}$ & Reference \\
\hline \multirow[t]{5}{*}{ Austria $^{5}$} & FCR (symmetrical) & $14.76 / 7.38$ & NA & {$[22],[23]$} \\
\hline & aFRR+ (weekly average) & 1.12 & 101.73 & \\
\hline & aFRR- (weekly average) & 2.1 & -49.61 & \\
\hline & mFRR+ (weekly average) & 1.25 & 171.9 & \\
\hline & mFRR- (weekly average) & 1.52 & -232.57 & \\
\hline \multirow[t]{9}{*}{ Denmark } & $\mathrm{FCR}+(\mathrm{DK} 1$, daily $)$ & 17.98 & NA & {$[16],[24],[25]$} \\
\hline & FCR- (DK1, daily) & 1.56 & NA & \\
\hline & $\begin{array}{l}\text { FCR-N (DK2, yearly, } \\
\text { symmetrical) }\end{array}$ & $25.34 / 12.67$ & NA & \\
\hline & FCR-D+ (DK2, yearly) & 6.18 & $\mathrm{NA}$ & \\
\hline & $\mathrm{aFRR}+(\mathrm{DK} 1, \mathrm{DK} 2)$ & $90 / 45^{6}$ & 13.4 & \\
\hline & aFRR- (DK1, DK2) & $90 / 45^{7}$ & -13.4 & \\
\hline & mFRR+ (DK1) & 0.62 & 37.43 & \\
\hline & mFRR- (DK1) & not traded & 10.02 & \\
\hline & mFRR+ (DK2) & not traded & 80.16 & \\
\hline
\end{tabular}




\begin{tabular}{|c|c|c|c|c|}
\hline Country & Product & $\begin{array}{l}\text { Availability } \\
\text { price } \\
{[€ / \mathrm{MW} / \mathrm{h}]}\end{array}$ & $\begin{array}{l}\text { Utilisation price } \\
\text { [€/MWh] }\end{array}$ & Reference \\
\hline & mFRR- (DK2) & not traded & 19.63 & {$[26],[23]$} \\
\hline \multirow[t]{5}{*}{ Germany } & FCR (symmetrical) & $15.27 / 7.64$ & - & \\
\hline & aFRR + & 4.25 & 54.85 & \\
\hline & aFRR- & 0.85 & 17.14 & \\
\hline & mFRR+ & 0.98 & 106.2 & \\
\hline & mFRR- & 0.86 & 78.83 & \\
\hline \multirow[t]{8}{*}{ Finland } & $\begin{array}{l}\text { FCR-N (yearly, } \\
\text { symmetrical) }\end{array}$ & $17.42 / 8.71$ & $\begin{array}{l}77 \text { (up) } \\
22 \text { (down) }\end{array}$ & [27], [28] \\
\hline & $\begin{array}{l}\text { FCR-N (hourly, } \\
\text { symmetrical) }\end{array}$ & $34.7 / 17.36$ & $\begin{array}{l}77 \text { (up) } \\
22 \text { (down) }\end{array}$ & \\
\hline & FCR-D+ (yearly) & 4.5 & NA & \\
\hline & FCR-D+ (hourly) & 30.3 & NA & \\
\hline & aFRR+ & 23.4 & 77 & \\
\hline & aFRR- & 19.7 & 22 & \\
\hline & mFRR+ & 3.6 & 77 & \\
\hline & mFRR- & not traded & 22 & \\
\hline \multirow[t]{8}{*}{ France } & $\mathrm{FCR}+$ & 9.18 & 32.47 & \\
\hline & FCR- & 9.18 & 32.98 & {$[23],[29],[30]$} \\
\hline & aFRR+ & 10.04 & 27.14 & \\
\hline & aFRR- & 10.04 & 26.38 & \\
\hline & mFRR+ & 2.37 & 50.84 & \\
\hline & mFRR- & not traded & 32.78 & \\
\hline & $\mathrm{RR}+$ & 2.23 & 47.97 & \\
\hline & RR- & not traded & 18.50 & \\
\hline \multirow[t]{7}{*}{ Ireland } & FRR+ & 2.06 & NA & \\
\hline & $\mathrm{POR}+$ & 3.09 & NA & \\
\hline & SOR+ & 1.87 & NA & $\begin{array}{l}\text { [31], survey, cross } \\
\text { checked with [32] } \\
\text { and [33]. }\end{array}$ \\
\hline & TOR $1+$ & 1.48 & NA & \\
\hline & TOR $2+$ & 1.18 & NA & \\
\hline & $\mathrm{RR}+$ (synchronized) & 0.24 & NA & \\
\hline & $\mathrm{RR}+($ desynchronized $)$ & 0.53 & NA & \\
\hline \multirow[t]{4}{*}{ Netherlands } & FCR (symmetrical) & $14.91 / 7.46$ & NA & \\
\hline & aFRR (symmetrical) & $12 / 6$ & $\begin{array}{l}55 \text { (up) } \\
16.93 \text { (down) }\end{array}$ & \\
\hline & mFRRda+ & 1.28 & 147 & \\
\hline & mFRRda- & not traded & -74 & [34], [23] \\
\hline
\end{tabular}




\begin{tabular}{|c|c|c|c|c|}
\hline Country & Product & $\begin{array}{l}\text { Availability } \\
\text { price } \\
\text { [€/MW/h] }\end{array}$ & $\begin{array}{l}\text { Utilisation price } \\
\text { [€/MWh] }\end{array}$ & Reference \\
\hline \multirow[t]{5}{*}{ Norway } & FCR-N (symmetrical) & 241117 & 26.41 (up) & \\
\hline & $\mathrm{aFRR}+$ & 705 & 3231 & \\
\hline & aFRR- & 6.78 & 29.30 & \\
\hline & mFRR+ & 1.44 & 34.39 & \\
\hline & mFRR- & not traded & 17.72 & \\
\hline \multirow[t]{5}{*}{ Slovenia } & aFRR (symmetrical) & $20.89 / 10.44$ & $\begin{array}{l}55.8 \text { (up) } \\
18.6 \text { (down) }\end{array}$ & \\
\hline & mFRR+ & 5.71 & 173.8 & \\
\hline & mFRR- & 4.84 & -180 & \\
\hline & $\mathrm{RR}+$ & NA & 43.9 & \\
\hline & RR- & NA & 13 & \\
\hline \multirow[t]{14}{*}{ Sweden $^{8}$} & \multirow{6}{*}{ FCR-N (symmetrical) } & \multirow{6}{*}{$25.65 / 12.83$} & $\begin{array}{l}\frac{\text { SE1 }}{35.89 \text { (up) }} \\
20.01 \text { (down) }\end{array}$ & \multirow[t]{14}{*}[38]{$,[39],[40],[28]$} \\
\hline & & & SE2 & \\
\hline & & & 34.06 (up) & \\
\hline & & & 20.81 (down) & \\
\hline & & & $\begin{array}{l}\underline{\text { SE3 }} \\
41.07 \text { (up) } \\
20.78 \text { (down) }\end{array}$ & \\
\hline & & & $\begin{array}{l}\text { SE4 } \\
66.05 \text { (up) } \\
24.22 \text { (down) }\end{array}$ & \\
\hline & \multirow{6}{*}{ FCR-D (symmetrical) } & \multirow{6}{*}{6.21} & $\begin{array}{l}\underline{\mathrm{SE} 1} \\
35.89 \text { (up) } \\
20.01 \text { (down) }\end{array}$ & \\
\hline & & & $\underline{\mathrm{SE2}}$ & \\
\hline & & & 34.06 (up) & \\
\hline & & & 20.81 (down) & \\
\hline & & & $\begin{array}{l}\underline{\text { SE3 }} \\
41.07 \text { (up) } \\
20.78 \text { (down) }\end{array}$ & \\
\hline & & & $\begin{array}{l}\text { SE4 } \\
66.05 \text { (up) } \\
24.22 \text { (down) }\end{array}$ & \\
\hline & $\mathrm{aFRR}+\mathrm{SE} 1$ & 18 & 35.89 & \\
\hline & aFRR-SE1 & 9.5 & 20.01 & \\
\hline
\end{tabular}




\begin{tabular}{|c|c|c|c|c|}
\hline Country & Product & $\begin{array}{l}\text { Availability } \\
\text { price } \\
\text { [€/MW/h] }\end{array}$ & $\begin{array}{l}\text { Utilisation price } \\
\text { [€/MWh] }\end{array}$ & Reference \\
\hline & $\mathrm{aFRR}+\mathrm{SE} 2$ & 18 & 34.06 & \\
\hline & aFRR- SE2 & 9.5 & 20.81 & \\
\hline & $\mathrm{aFRR}+\mathrm{SE} 3$ & 18 & 41.07 & \\
\hline & aFRR-SE3 & 9.5 & 20.78 & \\
\hline & $\mathrm{aFRR}+\mathrm{SE} 4$ & 18 & 66.05 & \\
\hline & aFRR-SE4 & 9.5 & 24.22 & \\
\hline & $\mathrm{mFRR}+\mathrm{SE} 1$ & NA & 35.89 & \\
\hline & mFRR- SE1 & NA & 20.01 & \\
\hline & mFRR+ SE2 & NA & 34.06 & \\
\hline & mFRR- SE2 & NA & 20.81 & \\
\hline & $\mathrm{mFRR}+\mathrm{SE} 3$ & NA & 41.07 & \\
\hline & mFRR- SE3 & NA & 20.78 & \\
\hline & $\mathrm{mFRR}+\mathrm{SE} 4$ & NA & 66.05 & \\
\hline & mFRR-SE4 & NA & 24.22 & \\
\hline \multirow[t]{4}{*}{ Switzerland } & FCR (symmetrical) & $14.63 / 7.32$ & NA & \multirow[t]{4}{*}[23]{$,[14],[41]$} \\
\hline & aFRR (symmetrical) & $37.65 / 18.82$ & $\begin{array}{l}50.82 \text { (up) } \\
28.91 \text { (down) }\end{array}$ & \\
\hline & mFRR+ (weekly) & 2.38 & 73.07 & \\
\hline & mFRR- (weekly) & 4.03 & -65.05 & \\
\hline \multirow{4}{*}{$\begin{array}{l}\text { United } \\
\text { Kingdom }\end{array}$} & FFR (symmetrical) (FCR) & $4.03 / 2.02$ & NA & \multirow[t]{4}{*}[8]{$,[42],[43]$} \\
\hline & Fast Reserve+ $(\mathrm{mFRR}+)$ & 5.3 & 2.77 & \\
\hline & DTU- (RR-) & 1.8 & 73.08 & \\
\hline & STOR flex+ (RR+) & 1.07 & 132.09 & \\
\hline
\end{tabular}

\section{DSO Survey Results}

For DSO grid services, no relevant established market with transparent price information, product definitions and market rules were found in Europe. The survey responses were unanimous in that none of the DSOs could valuate ${ }^{9}$ congestion management, capacity management or voltage control (where included). Moreover, none could offer any response to the hours of availability these services would typically be provided in a year. From this it can be understood that no DSO grid service markets exist as of yet. Some responses were explicit in stating this outright in Table 7. The following responses broadly summarise the main positions of the DSOs:

- in Latvia the TSO provides these services rather than the DSO;

- the Czech DSO has no legal right to procure non-frequency ancillary services (AS) ${ }^{10}$,

- in some cases, services do not exist on the distribution level;

- in other cases, congestion problems are not being experienced in the distribution network and, therefore, do not warrant a need for DSO grid services as of yet;

- some DSOs do not perceive load flexibility as being valuable while others do not expect any kind of revenue generation from it in the future as it will be expected to become a mandatory requirement for loads in any case, similar to other generators;

- as mentioned prior in Spain and Portugal, loads have no legal right to provide AS; and 
- voltage control on the medium voltage (MV) level is provided via different means in Bulgaria, Czech Republic and Latvia.

Further details can be found in Table 7.

\section{TABLE 7 \\ SUMMARY OF KEY STATEMENTS FROM THE DSO SURVEY}

\begin{tabular}{|c|c|}
\hline Country / DSO & Summary \\
\hline $\begin{array}{l}\text { Bulgaria / CEZ } \\
\text { Distribution Bulgaria }\end{array}$ & $\begin{array}{l}\text { Survey not filled in }{ }^{11} \\
\text { The majority of the DSO grid consists of single medium voltage (MV) feeders } \\
\text { According to legislation DSOs cannot operate RES in real time } \\
\text { Voltage regulation in the distribution network, as part of voltage and reactive } \\
\text { power management in the power system, is tertiary regulation }\end{array}$ \\
\hline $\begin{array}{l}\text { Czech Republic / CEZ } \\
\text { Distribuce }\end{array}$ & $\begin{array}{l}\text { Retailers act as aggregators and will continue to have this role in Czech } \\
\text { Republic } \\
\text { Demand response is in place to deal with decreasing loads } \\
\text { Possible future grid services are defined by the European Commission's Clean } \\
\text { Energy Package, under which DSOs will only be allowed to procure non- } \\
\text { frequency Ancillary services (AS) } \\
\text { Voltage control: } \\
\text { - Is currently procured through reactive power from large generating } \\
\text { assets in the HV/MV grid with a wide reactive power range } \\
\text { - Is not remunerated by DSOs and is compulsory for all new } \\
\text { generation offering active power control in a narrow range } \\
\text { - the most promising and cost-effective way for DER integration on } \\
\text { the DSO level is via reactive power } \\
\text { It was pointed out that WP6 of a pilot project (InterFlex }{ }^{12} \text { ) focuses on flexibility } \\
\text { on the DER and EV side and it states that flexibility is foreseen as a future } \\
\text { requirement of DER or EV without remuneration. }\end{array}$ \\
\hline $\begin{array}{l}\text { Ireland / ESB } \\
\text { Networks }\end{array}$ & $\begin{array}{l}\text { Does not perceive flexible high-power load as valuable. } \\
\text { Aggregators are on the market but ESB has no contractual relationships with } \\
\text { them }\end{array}$ \\
\hline $\begin{array}{l}\text { Latvia / Sadales tikls } \\
\text { AS }\end{array}$ & $\begin{array}{l}\text { - Latvian DSOs are not working to create flexibility services yet given } \\
\text { that Latvia has few distributed generating units } \\
\text { - Congestion \& capacity management are provided by TSO. } \\
\text { - Voltage regulation in MV is provided via local regulation of transformer } \\
\text { - voltage output if necessary } \\
\text { - No aggregators are active in DSO grid services provision }\end{array}$ \\
\hline $\begin{array}{l}\text { Slovenia / Regional } \\
\text { distribution company: } \\
\text { Elektro-Gorenjska }\end{array}$ & $\begin{array}{l}\text { - Elektro-Gorenjska is not experiencing any congestion or capacity } \\
\text { problems } \\
\text { - Elektro-Gorenjska has no involvement in DSO grid services } \\
\text { - No aggregators are active in DSO grid services provision } \\
\end{array}$ \\
\hline Spain / Endesa & $\begin{array}{l}\text { - Participation of loads in the provision of AS is not allowed in the } \\
\text { Iberian Peninsula } \\
\text { - No specific services have been developed for the distribution } \\
\text { network that could be covered in the future by demand aggregators. }\end{array}$ \\
\hline
\end{tabular}




\begin{tabular}{|l|l|}
\hline & $\begin{array}{l}\text { Based on the market design principle of the necessity for suppliers to } \\
\text { participate in equal conditions, if demand was allowed to participate in } \\
\text { AS then no payment for capacity }(€ / \mathrm{MW} / \mathrm{yr}) \text { would be awarded or would } \\
\text { be justifiable for congestion management until the scheme were } \\
\text { implemented for generators alike }\end{array}$ \\
\hline
\end{tabular}

\section{CONCLUSION AND OUTLOOK}

Surveys were distributed to 36 TSOs and 143 DSOs in the EU in an effort to obtain primary data on electricity grid service markets. Identified were 85 TSO grid services within 12 countries as being commercially and technically feasible candidates for distributed variable loads, such as water electrolysers - a key technology of sustainable hydrogen production-that can offer high operational flexibility for the grid services identified. 12 EU Horizon 2020 project that explores pathways to adapt and modernize the electric distribution system in line with the objectives of the 2020 and 2030 climate-energy packages of the European Commission.

TSO grid services are generally valorised by two means, remuneration for the availability ("power reserve') of the Reserve Providing Unit and remuneration for utilisation ('energy'), whereas the distribution system operator grid services were found to have no relevant established market with transparent price information and product definitions in Europe. The TSO grid service markets differ among countries with regard to market rules, market transparency and price levels. For example, average remuneration of availability for FCR in Norway (FCR-N) is $3.4 € / \mathrm{MWh}$ while in Finland (FCR-N hourly) it is $34.7 € / \mathrm{MWh}$. Furthermore, availability of aFRR- is remunerated in Finland at approximately 23 times higher than in Germany, with similar spreads found with the other products. Overall, the most favourable availability prices were found in Finland, Switzerland and Denmark and the most favourable utilisation prices were found in Austria, Germany and the UK. Congestion management, capacity management and voltage control are grid services not offered on the DSO level for different reasons depending on the country. Most changes in the next five years are particularly expected in those countries whose barriers to market entry for distributed variable loads are relatively high, whereas those countries whose markets are more advanced anticipate having shorter time resolution products. A general sentiment is that the harmonisation of the EU electricity balancing markets is expected to have the effect of converging market mechanisms, product prices, types and requirements for efficient cross-border trading, and crucially improve data transparency.

\section{ACKNOWLEDGEMENT}

This research was financially supported by the EU/ FCH JU under QualyGridS (Project 735485, www.qualygrids.eu), work package 6.1, and the Swiss State Secretariat for Education, Research and Innovation (SERI) under contract number 17.00009. We thank all respondents, experts and TSO liaisons who were involved in the survey and/or validation of the survey. Their insight and expertise greatly assisted the research as a whole. Without their participation and input, the survey and its validation could not have been successfully conducted.

\section{ENDNOTES}

1. legal entities responsible for the operation of a number of power generating modules and/or demand facilities by means of pooling for the purpose of offering grid services

2. Auctions, tenders and market platforms

3. hybrid

4. The common Nordic price for all hours of the next 24-hour period on the day-ahead spot market.

5. Weekly averages are time weighted values based on weekly peak and off-peak products.

6. Course estimate based on January and August Contracts 2016

7. Course estimate based on January and August Contracts 2016 
8. Only mFRR is currently demanded by Swedish TSO, hence Swedish aFRR and FCR are not included in the price comparison shown in Table 6.

in $€ / \mathrm{MW} / \mathrm{h}$ and year of availability

10 voltage control, inertia and black-start capability among others

correspondence via email clarifying position in response to survey

EU Horizon 2020 project that explores pathways to adapt and modernize the electric distribution system in line with the objectives of the 2020 and 2030 climate-energy packages of the European Commission.

\section{REFERENCES}

Balancing Statistics in APG Control Area. (2018). [Online]. Retrieved October 24, 2018, from https://www.apg.at/en/markt/netzregelung/statistik

Bertoldi, P., Zancanella, P., \& Boza-Kiss, B. (2016). Demand Response status in EU Member States.

Elexon. (2018). Bid Offer Data|BMRS. [Online]. Retrieved October 4, 2018, from https://www.bmreports.com/bmrs/?q=balancing/bidoffer

Energinet. (2018). Energi Data Service. [Online]. Retrieved October 12, 2018, from https://www.energidataservice.dk/

Energinet. (2018). Historical data. [Online]. Retrieved October 25, 2018, from http://osp.energinet.dk/_layouts/Markedsdata/framework/integrations/markedsdatatemplate.aspx? language $=\mathrm{en}$

Entso-e. (2013). Supporting Document for the Network Code on Load-Frequency Control and Reserves (NC LFCR).

entsoe. (2017). entsoe transparency platform: Price of Reserved Balancing Reserves. [Online]. Retrieved November 4, 2017, from

https://transparency.entsoe.eu/balancing/r2/balancingVolumesReservationPrice/show?name=\&de faultValue $=$ false $\&$ viewType $=$ TABLE $\&$ areaType $=$ MBA $\&$ atch $=$ false $\&$ dateTime dateTime $=03.09$. 2019+00:00\%7CUTC\%7CDAY\&dateTime.endDateTime $=01.10 .2019+00: 00 \% 7 C U T C \% 7 C D A$ Y\&contractType

Imboden, C., \& Harari, O. (2018). Survey for TSOs conducted for WP6.1.

National Grid. (2017). Electricity balancing services | National Grid ESO. [Online]. Retrieved October 4, 2017, from https://www.nationalgrideso.com/balancing-services

NODES AS. (2018). A fully integrated marketplace for flexibility. Lysaker.

Nordpool. (2017). Historical Market Data. [Online]. Retrieved November 4, 2017, from https://www.nordpoolgroup.com/historical-market-data/

Smart Energy Demand Coalition (SEDC). (2017). Explicit Demand Response in Europe Mapping the Markets 2017.

Swissgrid. (2018). Ausschreibungen. [Online]. Retrieved October 4, 2017, from https://www.swissgrid.ch/de/home/customers/topics/ancillary-services/tenders.html

USEF Foundation and Universal Smart Energy Framework. (2015). USEF: The Framework explained. Wgas, E.E. (2017). SURVEY ON ANCILLARY SERVICES PROCUREMENT, BALANCING MARKET DESIGN 2016." ENTSO-E. 